\title{
American witnesses testify in Japan about AIDS risks
}

Tokyo. Litigation by Japanese haemophiliacs against the Japanese government and blood product manufacturers reached a crucial stage last week. The patients are seeking compensation for failure to protect them from blood products contaminated with human immunodeficiency virus (HIV).

The latest development is the testimony in Osaka district court by a former official of the Centers for Disease Control (CDC) at Atlanta in the United States. Donald Francis, former assistant director of viral diseases and coordinator of the AIDS laboratory at CDC, testified that by early 1983 it was clear that US blood supplies were probably contaminated with the transmissible agent responsible for AIDS.

Yet, during 1983-85, Japan dramatically increased its imports of untreated US blood products (see figure) and, as a result, many of Japan's 5,000 haemophiliacs were infected with HIV. Francis said the tragedy could have been avoided.

As in France (see Nature 363, 491; 1993), Japan was slow to react to the dangers posed to blood supplies by AIDS. Blood coagulant concentrates for haemophiliacs which had been heat-treated to kill HIV and other viruses were not approved for sale in Japan until July 1985, despite their availability in the United States from March 1983. Blood product manufacturers continued to advertise untreated products in Japan without warning until late 1985; Japanese haemophiliacs used them into 1986.

The Osaka suit was filed in 1989 by a group of haemophiliacs and seeks about $\$ 1$ million each in compensation from the government and five pharmaceutical companies - Green Cross Corporation (Midori Juji), the Chemo-Sero-Therapeutic Research Institute(Kaketsuken), Baxter Travenol, Bayer Yakuhin and Nippon Zoki Pharmaceutical Company. Together with a similar suit filed slightly later in Tokyo, the number of plaintiffs has reached 92 , but several have died and are now represented by their families.

Francis says of his court experience that he was "almost tearful" in the presence of the infected haemophiliacs. He says that by early 1983 the danger posed to US blood supplies by AIDS was "absolutely black and white", when six cases of AIDS in five adults and one baby had been traced to transfusions of blood from donors who subsequently developed AIDS.

Francis said that CDC convened a meeting in January 1983 to explain the dangers to blood banks, blood product manufacturers and physicians, and to suggest possible solutions. "But we were on totally different wavelengths." The blood industry argued that six cases of AIDS in 6 million donors indicated a one-in-a-million chance of infection. Francis recalls that the meeting ended with his asking, "How many more people have to die before you understand?"

Despite these warnings, blood product manufacturers increased their imports to Japan of untreated concentrates as Japan began a massive "modernization" drive to introduce concentrates for use by haemophiliacs in the home. The price of the concentrates was then much higher in Japan than in the United States, providing a strong incentive to sell in Japan, especially after the United States began to withdraw untreated

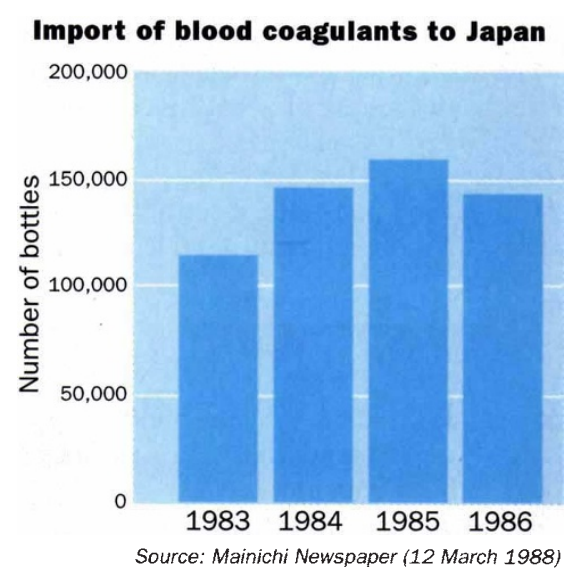

products in 1984. Doctors and hospitals in Japan also profited by buying products at discount and claiming the higher official price from insurance schemes.

According to Francis, lawyers for the plaintiffs have shown him a memorandum from one importer saying that the company had consulted CDC and had been assured there was no danger to Japanese blood product supplies. "I don't know who they spoke to but it must have been someone in the lead poisoning department."

"Inability to translate hot cutting edge news in science to practical health care programs" also played a key role in the tragedy, Francis says. "There were only a dozen experts on AIDS in the world at that time.... It was in part a failure in marketing." This view seems to be borne out by Shelby Dietrich, head of the Hemophilia Center of Huntington Hospital in California and former chairman of the medical board of the World Federation of Hemophilia, who has testified for the defence in Tokyo. She said she was not convinced that a blood-borne virus was the primary cause of AIDS until a paper was published in Science by Robert Gallo and colleagues in May 1984. And the first major change in treatment of haemophiliacs was not made at her hospital until September
1984, when it became clear that heat treatment killed HIV.

Dietrich's testimony reveals the problems that doctors faced in weighing up the risks and benefits of various blood products in 1983-84. After the January 1983 CDC meeting, her hospital reverted to treatment of limited groups of patients (the young and those with mild haemophilia) with cryoprecipitate made from a much smaller pool of donors than concentrates. But the cryoprecipitate requires treatment in hospital. Complications due to delay in treatment can occur and one patient died as a result. Many patients then chose to revert to the concentrates which can be self-administered.

When heat-treated concentrates became available in the United States in March 1983, Dietrich and other doctors initially used them only in a limited number of patients because of fear of side-effects. Only when heat treatment was shown to kill HIV in September 1984 did their use became widespread in the United States.

In 1983, the risk of AIDS infection from blood products appeared to be small. People failed to recognize the dangers of the long incubation period of at least two years established by the evidence from the 1982 transfusion cases, Francis says. He blames the US Food and Drug Administration (FDA) for failing to act quickly enough. "We at CDC tried to pass the baton to FDA at the January 1983 meeting", but "Reagan was decreasing budgets and the government turned the responsibility over to the blood banks". The "terrifying thing", he says, "is that this worldwide disaster is the result of decisions made by a remarkably small group of people led by Americans."

At the 1983 meeting, Francis says he advocated the introduction of screening of blood donations for hepatitis B as an anonymous way to eliminate most male homosexual donors, a high-risk group for AIDS, from the donor pool. But this idea was not adopted. And effective screening of US blood supplies did not come until the introduction of the HIV antibody test in 1985.

Alarmed by the reports from the United States, Japan's Ministry of Health and Welfare set up a committee of academics in 1983 to look into the possibility of reintroducing cryoprecipitate instead of concentrates. In March 1984 the committee opted for concentrates. Clinical trials of heat-treated concentrates began around this time in Japan but were not approved for use until more than a year later.

Ministry officials argue that they acted as quickly as possible. But Francis and lawyers for the Japanese plaintiffs point out that the dangers of viral contamination of concentrates made from the pooled blood of thousands of donors were foreseen in the 1970s before AIDS even appeared, and a German company developed heat treatment in 1978 to eliminate hepatitis infection. Court cases like this in Japan typically take years to resolve.

David Swinbanks 